\title{
Unfair prejudice in United Kingdom Company Law
}

\author{
Zhengyang Fan \\ Master of Laws \\ The University of Edinburgh \\ Binzhou City, Shandong Province, China \\ Email: celtfanfan [AT] gmail.com
}

\begin{abstract}
It is common that the majority shareholders in a corporation take action that unfairly prejudices the minority. ${ }^{1}$ A majority shareholder occupies a dominant position in the decision-making process of the company's affairs and can control the company with the principle of majority rule. ${ }^{2}$ In the process of company development, the interests of the majority shareholders may diverge from the interests of the company. ${ }^{3}$ In this case, the majority of shareholders may engage in unfair prejudice conduct that harm the interests of the company and minority shareholders for their own benefit. Consequently, to some extent, the principle of majority rule provides the possibility for the controlling shareholders to abuse voting rights, which often constitutes damage to the interests of minority shareholders. In addition, due to the reliance on the controlling shareholder, the directors tend to only take into account the interests of the majority shareholders, with the result that ignore the rights and interests of noncontrolling shareholders. ${ }^{4}$ Especially in private companies, minority shareholders not only cannot sell their shares in the stock exchanges without restrictions to exit the company, but also may be subject to more severe oppression by the actual controller of the company. ${ }^{5}$ When minority shareholders cannot obtain relief within the company, it is necessary for aggrieved shareholders to bring an action against the majority shareholders to protect their rights.
\end{abstract}

However, under the rule in Foss $v$ Harbottle, ${ }^{6}$ shareholders only be allowed to sue if they meet the exceptions. ${ }^{7}$ Due to the limited application scope of these exceptions, the aggrieved shareholders are often unable to get timely and effective relief in practice. In response to this problem, statutory unfair prejudice provisions are introduced to balance the interests of majority shareholders and minority shareholders, and to prevent shareholder oppression in corporate governance. It emphasizes judicial intervention to protect the legitimate interests of shareholders. ${ }^{8}$ Compared with just and equitable winding up and derivative action, the unfair prejudice is regarded as a mechanism for minority protection as it covers a variety of remedies and leaves the court with greater discretion.

\section{THE BACKGROUND OF UNFAIR PREJUDICE}

\subsection{The History of Unfair Prejudice}

The unfair prejudice provisions originated from the modification of the alternative remedy to winding up in cases of oppression provided in the Companies Act 1948. ${ }^{9}$ According to the Section 210(1) of the Companies Act 1948, any member of a company who complains that the affairs of the company are being conducted in an oppressive manner to

\footnotetext{
${ }^{1}$ Derek French, Stephen W Mayson and Christopher Ryan, Mayson, French \& Ryan On Company Law (2017-2018 edn, Oxford University Press 2017) 572

${ }^{2}$ Sarah Worthington and L. S. Sealy, Sealy and Worthington's Text, Cases and Materials in Company Law (11th edn, Oxford University Press 2016) 715

${ }^{3}$ Derek French, Stephen W Mayson and Christopher Ryan, Mayson, French \& Ryan On Company Law (2017-2018 edn, Oxford University Press 2017) 575

${ }^{4}$ Zhong Xing Tan, 'Unfair Prejudice from beyond, beyond Unfair Prejudice: Amplifying Minority Protection in Corporate Group Structures' (2014) 14 J Corp L Stud 367

${ }^{5}$ Sarah Worthington and L. S. Sealy, Sealy and Worthington's Text, Cases and Materials in Company Law (11th edn, Oxford University Press 2016) 722

${ }^{6}$ Foss $v$ Harbottle, [1843] 3 WLUK 93

${ }^{7}$ Paul L Davies and Sarah Worthington, Gower's Principles of Modern Company Law (10th edn, Sweet \& Maxwell 2016) 960

${ }^{8}$ Paul L Davies and Sarah Worthington, Gower's Principles of Modern Company Law (10th edn, Sweet \& Maxwell 2016) 964

${ }^{9}$ Companies Act 1948, section 210(1)
} 
some part of the members may make an application to the court by petition for an order under this section. ${ }^{10}$ However, for the term "oppressive", ${ }^{11}$ the House of Lords in Meyer $v$ Scottish Cooperative Wholesale Society Ltd, interprets that it meant "burdensome, harsh and wrongful". ${ }^{12}$ The interpretation of oppression has set a higher threshold for this provision, which has led to few applications in practice. To make this clear, it recommended the use of the term "unfairly prejudicial", which Parliament somewhat adopted in Section 75 of the Companies Act 1980. ${ }^{13}$ This section is reproduced in the Section 459 of the Companies Act 1985 and Section 994 under the Companies Act 2006. ${ }^{14}$

\subsection{The Concept of Unfair Prejudice}

\section{a. At the Legislative Level}

The statutory unfair prejudice provisions are provided in Sections 994 and 996 of the Companies Act $2006 . .^{15}$ To be specific, when the affairs of the company are being or have been conducted in a manner that is unfairly prejudicial to the interests of members, the aggrieved shareholders could make an application to the court according to the Section 994 for the remedy under the Section $996 .^{16}$ The defining feature of the unfair prejudice is that it is completely vague, with the result that the court is capable of interpreting the provisions as they felt would be fair. ${ }^{17}$ After hearing a case, the court could make an order as it thinks fit under Section $996 .{ }^{18}$ Based on this, the judge is empowered with wide discretion to determine what constitutes an unfair prejudice conduct to the interests of members and what remedies should be given to the aggrieved shareholders. It should be noted that the purpose of Sections 994 and 996 of the Companies Act 2006 is not to interpret the concept of "unfair prejudice ", but to recognize the litigation rights of shareholders based on it.

\section{b. At the Judicial Level}

What is the unfair prejudice conduct? The Companies Act 2006 does not answer this question. ${ }^{19}$ As a result, there is no clear standard for determining the conduct and remedy of the unfair prejudice in statute law. However, in judicial practice, the judge did not give up the attempt to analyze this concept.

For example, in $O^{\prime}$ Neill $v$ Phillips, Phillips was its sole shareholder and director. ${ }^{20} \mathrm{He}$ appointed O'Neill to the board of directors and gave him a $25 \%$ shareholding in the company. ${ }^{21}$ They discussed that O'Neill would take over the sole management of the company, and he was accordingly allowed a $50 \%$ share of the profits of the business. ${ }^{22}$ Shortly afterwards, Phillips retired and leaved O'Neill as de facto managing director. ${ }^{23}$ However, the company was in trouble, and Phillips resumed control of the company and repudiated the profit-sharing agreement. ${ }^{24} \mathrm{O}^{\prime}$ Neill filed a petition, arguing that Phillips' conduct amounted to unfair prejudice. ${ }^{25}$ Lord Hoffmann noted that the background against which the concept of fairness has the following two features. ${ }^{26}$ On the one hand, unless there has been some breach of the articles of associations or shareholder agreements, a member of a company will not generally be entitled to complain of

\footnotetext{
${ }^{10}$ Ibid.

${ }^{11}$ Derek French, Stephen W Mayson and Christopher Ryan, Mayson, French \& Ryan On Company Law (2017-2018 edn, Oxford University Press 2017) 587

${ }^{12}$ Meyer v Scottish Cooperative Wholesale Society Ltd, [1959] AC 324

${ }^{13}$ Companies Act 1980, section 75

${ }^{14}$ Companies Act 1985, section 459; Companies Act 2006, section 994

${ }^{15}$ Companies Act 2006, section 994, 996

${ }^{16}$ Sarah Worthington and L. S. Sealy, Sealy and Worthington's Text, Cases and Materials in Company Law (11th edn, Oxford University Press 2016) 727

${ }^{17}$ Arthur R Pinto, 'Protection of Close Corporation Minority Shareholders in the United States' (2014) 62 Am J Comp L Supp 361

${ }^{18}$ Companies Act 2006, section 996

${ }^{19}$ Companies Act 2006

${ }^{20}$ O'Neill v Phillips, [1999] 1 W.L.R. 1092

${ }^{21} \mathrm{Ibid}$

22 Ibid.

${ }^{23}$ Ibid.

${ }^{24}$ Ibid.

${ }^{25}$ Ibid.

${ }^{26}$ Ibid.
} 
unfairness. ${ }^{27}$ On the other hand, for the sake of equitable considerations, it is unfair that conducting the affairs of the company to rely on their strict legal powers under the articles of associations or shareholder agreements in some cases. ${ }^{28}$

In Grace v Biagioli, ${ }^{29}$ the Court of Appeal further clarified Lord Hoffmann's views on the concept of unfair prejudice. Judge Patten stated that an assessment that conduct is unfair should take into consideration of the legal background of the corporate structure. ${ }^{30}$ This will usually take the form of the articles of association and any collateral agreements between shareholders which identify their rights and obligations as members of the company. ${ }^{31}$ Both are subject to established equitable principles which may moderate the exercise of strict legal rights when insistence on the enforcement of such rights would be unreasonable. ${ }^{32}$ In other words, it will not constitute unfair conduct in accordance with the provisions of its articles or any other relevant and legally enforceable agreement, unless it would be inequitable for those agreements to be enforced in the particular circumstances under consideration.

Therefore, the concept of unfair prejudice must be applied judicially and the remedy which it is given by the court must be based upon equitable principles. The defining feature of the Section 994 action is that it is completely vague, which empowers the courts to interpret the provisions gradually as they felt would be fair. In other words, the concept of unfair prejudice itself does not require elemental interpretation, as long as in a specific case, the court can decide whether to intervene in the affairs of the company and provide remedy to the aggrieved shareholders. The concept of unfair prejudice free the court from technical considerations of legal right and confer a wide power to do what appeared just and equitable.

\section{KEY FEATURES OF UNFAIR PREJUDICE}

\subsection{Objectivity}

The concept of unfair prejudice is derived from "oppression". ${ }^{33}$ It is necessary to satisfy the subjective intention of the controlling shareholders when determining that their actions constitutes the oppression against minority shareholders under the Section 210 of the Companies Act 1948. ${ }^{34}$ However, according to statutory unfair prejudice provisions, the aggrieved shareholder is not required to prove that the actual controller of the company was clearly aware of the consequences of their conducts to minority shareholders when he carried out. ${ }^{35}$ In other words, constituting unfair prejudice conduct does not require the controlling shareholders to have the subjective intention of harming the noncontrolling shareholders. As long as the conduct of the majority shareholders has objectively caused oppression to the rights and interests of the minority shareholders, it shall be regarded as unfair prejudice conduct. In contrast, statutory unfair prejudice provision is more beneficial to protecting the interests of minority shareholders. In practice, when determining whether the conduct of controlling shareholders constitutes unfair prejudice, the court only needs to find out whether the consequences of their conduct is unfairly prejudicial to the interests of members, regardless of their subjective motive. ${ }^{36}$ In other words, the court usually bases on the objective criteria rather than the subjective when deciding cases about the unfair prejudice.

In fact, in the development of the common law, certain standards have been formed for unfair prejudice conduct. ${ }^{37}$ This means that the petitioner does not need to prove that the motive of the person who actually controls the company is

\footnotetext{
${ }^{27}$ Sarah Worthington and L. S. Sealy, Sealy and Worthington's Text, Cases and Materials in Company Law (11th edn, Oxford University Press 2016) 736

${ }^{28}$ Derek French, Stephen W Mayson and Christopher Ryan, Mayson, French \& Ryan On Company Law (2017-2018 edn, Oxford University Press 2017) 584

${ }^{29}$ Grace v Biagioli, [2006] 2 B.C.L.C. 70

${ }^{30}$ Ibid.

31 Ibid.

${ }^{32}$ Sarah Worthington and L. S. Sealy, Sealy and Worthington's Text, Cases and Materials in Company Law (11th edn, Oxford University Press 2016) 731

${ }^{33}$ Walter Woon Cheong Ming, 'A Note on Unfair Prejudice - Section 75 of the U.K. Companies Act 1980' (1983) 25 Malaya L Rev 396

${ }^{34}$ Companies Act 1948, section 210(1)

${ }^{35}$ Anthony O Nwafor, 'The Unfair Prejudice Remedy - A Relief for the Minority Shareholders' (2011) 13 U Botswana LJ 37

${ }^{36}$ Say H Goo and Rolf H Weber, 'The Expropriation Game: Minority Shareholders' Protection' (2003) 33 Hong Kong LJ 71

${ }^{37}$ Paul L Davies and Sarah Worthington, Gower's Principles of Modern Company Law (10th edn, Sweet \& Maxwell 2016) 959
} 
malicious ${ }^{38}$ that is, they knew that such conducts were unfair to the minority shareholders when carrying out company affairs. Even if the actual controller of the company did not maliciously harm the other members, as long as it caused unfair consequence against minority shareholders, the court found that the unfair prejudice was constituted. For example, in Saul D Harrison, Mr Purle, who appeared for the petitioner, said that the only test of unfairness was whether a reasonable bystander would think that the conduct was unfair. ${ }^{39}$ Its merit is to emphasise that the court is applying an objective standard of fairness. But the court point out that the standard of fairness must necessarily be laid down by the court, and it is more useful to examine the factors which the law actually takes into account. ${ }^{40}$ These factors are the rights of members stipulated in its articles of association and unwritten reasonable expectations among members, which conforms to the objective standard of the judgment of unfair damage. ${ }^{41}$ This provides a more specific way for the court to determining the unfair prejudice.

Hoffmann further pointed out in Saul D Harrison that the court must make an objective judgment based on reasonable principles. ${ }^{42}$ It can be seen that when the court determines whether the conduct lead to unfair consequence, the focus is on its impact rather than its nature. In other words, it was not necessary that the petitioner should have to show that the board was motivated by self-interest. ${ }^{43}$ Therefore, even if the actual controller of the company acts in good faith, their improper conduct may also be regarded as unfairly prejudicial to the interests of members.

Unfair prejudice is not equivalent to oppression, mainly because the constituent elements of unfair prejudice conduct do not include the subjective intention of the majority shareholders. This means that the aggrieved shareholder does not need to provide any evidence for the malicious motive of the controlling shareholders, which is conducive to the protection of minority shareholders. In addition, compared with derivative action, the objectivity of unfair prejudice also has a positive effect on non-controlling shareholder protection. In the derivative action, the court will consider the subjective elements of the fault of the directors and restrain the members with the principle of "clean hands". ${ }^{44}$ By contrast, under the statutory unfair prejudice provisions ${ }^{45}$ what the court concerned was whether the conduct of controlling shareholders caused an unfair consequence, which is an objective standard.

\subsection{Protection for the Legitimate Expectation of Minority Shareholders}

One of the prerequisites for the statutory unfair prejudice remedy is that the interests of the shareholders are being or have been infringed, where the interests of the shareholders are not limited to the interests provided in the articles of association and the shareholder agreement. ${ }^{46}$ For example, in Ebrahimi v Westbourne Galleries Ltd, Ebrahimi and Nazar were the sole shareholders in the company each owning $50 \%$ shares. ${ }^{47}$ Nazar's son joined the business with $10 \%$ of the company shares and was appointed to the board of directors. ${ }^{48}$ After a falling out between the directors Nazar and son called a company meeting, at which they passed an ordinary resolution to remove Ebrahimi as a director. ${ }^{49}$ Ebrahimi, clearly unsatisfied with this, applied to the court for a remedy to have the company wound up. ${ }^{50}$ In this case, the House of Lords stated that Ebrahimi had a legitimate expectation that his management function would continue. ${ }^{51}$ In other words, based on the personal relationship between the members of the company, it would be inequitable to allow the majority shareholders to use their rights against minority shareholders so as to force them out of the company. Lord Wilberforce noted that there is room for recognition of the fact that there are individuals, with rights, expectations and obligations in company law, which are not necessarily submerged in the articles of association and shareholder agreements. ${ }^{52}$ In this case, the court proposed to determine the interests of shareholder by the just and equitable principles, instead of limited

${ }^{38}$ Paul L Davies and Sarah Worthington, Gower's Principles of Modern Company Law (10th edn, Sweet \& Maxwell 2016) 964

${ }^{39}$ Re Saul D Harrison \& Sons Plc, [1995] 1 B.C.L.C. 14

40 Ibid.

${ }^{41}$ Sarah Worthington and L. S. Sealy, Sealy and Worthington's Text, Cases and Materials in Company Law (11th edn, Oxford University Press 2016) 735

${ }^{42}$ Re Saul D Harrison \& Sons Plc, [1995] 1 B.C.L.C. 14

${ }^{43}$ Paul L Davies and Sarah Worthington, Gower's Principles of Modern Company Law (10th edn, Sweet \& Maxwell 2016) 964

${ }^{44}$ Harkamal Atwal, 'Self-Interest, Justice and Reciprocity in Unfair Prejudice' (2004) 2004 UCL Jurisprudence Rev 270

${ }^{45}$ Companies Act 2006, section 994

46 Jennifer Payne, 'Shareholders' Remedies Reassessed' (2004) 67 Mod L Rev 500

${ }^{47}$ Ebrahimi v Westbourne Galleries Ltd, [1972] 2 W.L.R. 1289

${ }^{48}$ Ibid.

${ }^{49}$ Ibid.

${ }^{50}$ Ibid.

${ }^{51} \mathrm{Ibid}$

52 Ibid. 
to the articles of association of the company and written agreements, ${ }^{53}$ which provided a new way to realize the substantial protection of shareholders' interests.

Lord Hoffmann further stated in O'Neill $v$ Phillips that the court 's review should not stop at the articles of association of the company, because the legitimate expectations of minority shareholders may exist in the fundamental understanding among shareholders. ${ }^{54}$ In other words, it is unfair to carry on company affairs strictly in accordance with the company's articles of association in certain circumstances. The interests of shareholders should not be limited to narrow technical concept, and the legitimate expectations of shareholders should be protected by statutory unfair prejudice provisions. ${ }^{55}$ Furthermore, in Saul D Harrison, the court held that the unfair prejudice action does protect certain legitimate expectations from being disappointed. ${ }^{56}$ Lord Hoffmann noted that legitimate expectation often arises out of a fundamental understanding among the members which formed the basis of their association but was not put into contractual form. ${ }^{57}$ There is an assumption that each of the parties who has ventured his capital will also involve in the management of the company, and latter receive the return on his investment in the form of salary rather than dividend.

It can be seen that this legitimate expectation is based on mutual trust and understanding_among shareholders. For public companies, the relationship between shareholders is entirely based on commercial investment, with a result that the shareholders of a public company generally do not have other reasonable expectations than those provided in the articles of association. ${ }^{58}$ However, for private companies, especially quasi-partnership companies, such legitimate expectations are common among its members. ${ }^{59}$ In a small closed company, shareholders often have an expectation that they will participate in the management of the company while investing, such as being appointed as a director of the company. ${ }^{60}$ Usually in such companies, rights and interests of shareholders are not clearly defined in the articles of association or written agreements but are only based on the fundamental understanding and trust among shareholders. ${ }^{61}$ This understanding is the basis for shareholders to set up and operate the company jointly, even if it is not stipulated in a contract. To some extent, then, it can be argued that depriving shareholders of their legitimate expectation of management is to reduce their return on investment. In other words, the legitimate expectations of shareholders in a closed company are not only the expectation of the equity income, but also the earnings of the director or manager. ${ }^{62}$ Therefore, for a private company with a small number of members, this fundamental understanding among shareholders is the basis for its rights and interests. Any violation of such legitimate expectations by either party is unfair to the other. Consequently, this legitimate expectation is necessary to be protected by the unfair prejudice provisions in the company law.

\subsection{Mostly Reflected in Private Companies}

Although the statutory unfair prejudice provision is not only applicable to shareholders of the private company, public companies are usually not involved in it in practice. The relationship of shareholders in public companies is not as close as those in private companies. ${ }^{63}$ They are more concerned about the return of investment, that is, dividends. Moreover, when dividends do not meet their expectations or are oppressed by controlling shareholders, minority shareholders of the public company could freely sell the shares they hold on the stock exchange to exit the company. However, unlike public companies, private companies have fewer shareholders, and there is no clear distinction between ownership and control power of the company. These factors make the minority shareholders of private companies more likely to be oppressed, with more serious consequences.

\footnotetext{
${ }^{53}$ Sarah Worthington and L. S. Sealy, Sealy and Worthington's Text, Cases and Materials in Company Law (11th edn, Oxford University Press 2016) 735

${ }^{54}$ O'Neill v Phillips, [1999] 1 W.L.R. 1092

55 Sarah Worthington and L. S. Sealy, Sealy and Worthington's Text, Cases and Materials in Company Law (11th edn, Oxford University Press 2016) 734

${ }^{56}$ Re Saul D Harrison \& Sons Plc, [1995] 1 B.C.L.C. 14

57 Ibid.

${ }^{58}$ Sarah Worthington and L. S. Sealy, Sealy and Worthington's Text, Cases and Materials in Company Law (11th edn, Oxford University Press 2016) 735

${ }^{59}$ Derek French, Stephen W Mayson and Christopher Ryan, Mayson, French \& Ryan On Company Law (2017-2018 edn, Oxford University Press 2017) 583

${ }^{60}$ Arthur R Pinto, 'Protection of Close Corporation Minority Shareholders in the United States' (2014) 62 Am J Comp L Supp 361

${ }^{61}$ Derek French, Stephen W Mayson and Christopher Ryan, Mayson, French \& Ryan On Company Law (2017-2018 edn, Oxford University Press 2017) 578

${ }^{62}$ Arthur R Pinto, 'Protection of Close Corporation Minority Shareholders in the United States' (2014) 62 Am J Comp L Supp 361

${ }^{63}$ Ibid.
} 


\section{a. Particularity of Corporate Governance Structure}

A privately held company generally owned by a relatively small number of shareholders with close relationship. The shareholder of private companies is usually appointed as a director, and even manage the daily affairs of the company as a manager. In this way, the company's decision-making and operations are controlled by majority shareholders. When making decisions, it is inevitable that controlling shareholders will put their personal interests before the interests of the company and other shareholders, which gives rise to the possibility of majority shareholders abusing their power to oppress minority shareholders.

\section{b. Lack of Exit Scheme}

In general, members of a private company do not offer or sell their stock to the general public on the stock exchanges. ${ }^{64}$ Compared with public companies whose shares can be freely transferred, investors entering the private companies as minority shareholders often need to bear a greater risk. ${ }^{65}$ Due to the close relationship between shareholders of private companies, they may be restricted or prohibited by the articles of association or shareholders agreement when selling their shares. ${ }^{66}$ For example, the company's articles of association stipulate that the joining of new shareholders must be agreed by all members, which means that the transfer of shares is restricted. Therefore, the exit scheme of shareholders is one of the most serious problems for private companies, which prevents minority shareholders from being free to exit the company when they are oppressed by majority shareholders.

\section{c. Non-public}

There are higher information disclosure requirements in public companies, and their actions are subject to the attention and supervision of the government as well as the public. ${ }^{67}$ By contrast, privately held companies generally have fewer or less comprehensive reporting requirements and obligations for transparency, via annual reports, etc. ${ }^{68}$ than publicly traded companies do, with the result that their internal affairs are difficult to be supervised by government departments. Moreover, the decision-making process of private companies is not open to the public, and there is often a lack of accurate and effective records. This makes it difficult for minority shareholders to prove after being oppressed, so that aggrieved shareholders of private companies cannot receive effective remedies.

\subsection{The Discretion of the Court}

The defining feature of the Section 994 action is that it is completely vague which empowers the courts to interpret the provisions gradually as they felt would be fair. ${ }^{69}$ After hearing a case, a court may make such order as it thinks fit under Section $996,{ }^{70}$ that is, to decide each case on its particularity facts, which leaves the court with broad discretion. This is conducive to providing diverse and effective remedies to the minority shareholders who have been oppressed. Among them, share purchase orders are the most commonly used remedy. ${ }^{71}$ In addition, the court has the power to choose to issue various other orders to give aggrieved shareholders appropriate remedy. For example, in Kenyon Swansea Ltd, ${ }^{72}$ the minority shareholder presented his petition to restrain the controlling shareholder from voting on the proposed resolutions at the extraordinary general meeting which had been convened. The petition alleged that taking into consideration of the expectations to which the past relationship between the non-controlling shareholder, the passing of the resolutions would be an unfairly prejudicial conduct of the company to the minority shareholder's interests. ${ }^{73}$

\footnotetext{
${ }^{64}$ Sarah Worthington and L. S. Sealy, Sealy and Worthington's Text, Cases and Materials in Company Law (11th edn, Oxford University Press 2016) 742

${ }^{65}$ Arthur R Pinto, 'Protection of Close Corporation Minority Shareholders in the United States' (2014) 62 Am J Comp L Supp 361

${ }^{66}$ Harkamal Atwal, 'Self-Interest, Justice and Reciprocity in Unfair Prejudice' (2004) 2004 UCL Jurisprudence Rev 270

${ }^{67}$ Arthur R Pinto, 'Protection of Close Corporation Minority Shareholders in the United States' (2014) 62 Am J Comp L Supp 361

${ }^{68}$ Zhong Xing Tan, 'Unfair Prejudice from beyond, beyond Unfair Prejudice: Amplifying Minority Protection in Corporate Group Structures' (2014) 14 J Corp L Stud 367

${ }^{69}$ M Rishi Kumar Dugar, 'Minority Shareholders Buying Out Majority Shareholders - An Analysis' (2010) 22 Natl L Sch India Rev 105

${ }^{70}$ Companies Act 2006, section 996

${ }^{71}$ Derek French, Stephen W Mayson and Christopher Ryan, Mayson, French \& Ryan On Company Law (2017-2018 edn, Oxford University Press 2017) 586

${ }^{72}$ Re Kenyon Swansea Ltd, [1987] B.C.L.C. 514

${ }^{73}$ Ibid.
} 
In Bird Precision Bellows Ltd, the court noted that the statutory unfair prejudice provisions conferred on the court a wide discretion to do what was fair and equitable in all the circumstances, so as to put right the unfair prejudice remedies to a petitioner. ${ }^{74}$ This discretion extended to the terms of an order for the purchase of a petitioner's shares, with the result that the proper price for a petitioner's shareholding was the price which the court determined to be proper in all the circumstances of the case based on the discretion. In other words, once the court finds that the claim for unfair prejudice remedy has reasonable grounds, it must review all relevant circumstances and facts in order to find the most suitable way to relieve the aggrieved shareholders among these remedies. ${ }^{75}$

Therefore, the unfair prejudice conducts may be interpreted in different ways, and the power of such interpretation is the wide discretion of the court. However, this does not mean that the court can exercise its power without restriction. On the one hand, the court can use the discretion to give minority shareholders the effective unfair prejudice remedies, without being bound to specific provisions. On the other hand, the court must comprehensively consider the circumstances of each specific case in order to issue an appropriate order. ${ }^{76}$

\section{STRENGTHS OF UNFAIR PREJUDICE}

\subsection{Lower Threshold for Minority Protection}

Compared with the previous mechanisms for minority protection, such as just and equitable winding up and the alternative remedy in cases of oppression provided in Section 210 of the Companies Act 1948, ${ }^{77}$ the statutory unfair prejudice provision is more widely applied without strict restrictions. ${ }^{78}$ This has reduced the threshold for minority shareholders to obtain remedies to a certain extent, which makes it plays a significant role in protecting the interests of minority shareholders. First, the concept of unfair prejudice overcomes the shortcomings of the Section 210 in the Companies Act $1948,{ }^{79}$ such as the narrow scope of application. Shareholders applying for unfair prejudice remedy no longer have to meet the prerequisites for just and equitable winding up. Compared with being interpreted as harsh, wrongful and burdensome oppression, unfair prejudice provision has a wider scope of application and the court have a greater degree of discretion. ${ }^{80}$ Secondly, with the development of the common law, the rights of shareholders are no longer limited to the specific provisions of the articles of association but extended to the interests under reasonable expectations. ${ }^{81}$ In other words, the courts not only need to review the rights of shareholders clearly defined in the articles of association, but also pay attention to protecting the legitimate expectations of shareholders.

In addition, according to the unfair prejudice provisions in the Companies Act $2006,{ }^{82}$ even if the affairs of the company are not being or have been conducted in an unfairly prejudicial manner, but an actual or proposed act or omission of the company is or would be so prejudicial in the future, shareholders could also present a petition for unfair prejudice remedies. This effectively expands the scope of application and provides more comprehensive protection for minority shareholders.

The broad provisions of the unfair prejudice are actually sufficient to cover almost all improper conducts of the actual controller of the company. Regardless of whether the actual controller of the company is acting as a director or exercising power as a shareholder in the conduction of corporate affairs, it is subject to unfair prejudice provisions. This also applies to corporate groups. ${ }^{83}$ According to the common law, the concept of corporate affairs is not limited to the company but

\footnotetext{
${ }^{74}$ Re Bird Precision Bellows Ltd, [1986] 2 W.L.R. 158

${ }^{75}$ Sarah Worthington and L. S. Sealy, Sealy and Worthington's Text, Cases and Materials in Company Law (11th edn, Oxford University Press 2016) 749

${ }^{76}$ Sarah Worthington and L. S. Sealy, Sealy and Worthington's Text, Cases and Materials in Company Law (11th edn, Oxford University Press 2016) 717

${ }^{77}$ Companies Act 1948, section 210(1)

${ }^{78}$ Zhong Xing Tan, 'Unfair Prejudice from beyond, beyond Unfair Prejudice: Amplifying Minority Protection in Corporate Group Structures' (2014) 14 J Corp L Stud 367

${ }^{79}$ Companies Act 1948, section 210(1)

${ }^{80}$ Say H Goo and Rolf H Weber, 'The Expropriation Game: Minority Shareholders' Protection' (2003) 33 Hong Kong LJ 71

${ }^{81}$ Zhong Xing Tan, 'Unfair Prejudice from beyond, beyond Unfair Prejudice: Amplifying Minority Protection in Corporate Group Structures' (2014) 14 J Corp L Stud 367

${ }^{82}$ Companies Act 2006, section 994

${ }^{83}$ Anthony O Nwafor, 'The Unfair Prejudice Remedy - A Relief for the Minority Shareholders' (2011) 13 U Botswana LJ 37
} 
can be extended to the parent company or the subsidiary. For instance, in Rackind $v$ Gross, the court held that the affairs of the company are extremely wide and can include the affairs of a subsidiary. ${ }^{84}$ To be specific, conduct of the affairs of a parent company includes refraining from procuring a subsidiary to do something or condoning by inaction an act of a subsidiary, particularly under the circumstance that directors of the parent and the subsidiary are the same. ${ }^{85}$ Similarly, the court has power to issue an order regulating the future management of the affairs of a holding company where the affairs of its wholly-owned subsidiary that are being, or have been, conducted in an unfairly prejudicial manner, and the directors of the holding company are also directors of the subsidiary. Therefore, the application scope of unfair prejudice provisions is wide, which could provide more comprehensive and effective protection for the rights and interests of minority shareholders.

\subsection{The Effectiveness of Unfair Prejudice Remedies}

There are various remedies provided by the unfair prejudice provisions in the Companies Act $2006,{ }^{86}$ which is one of the main reasons why this mechanism is favored by aggrieved shareholders. The general concept of unfair prejudice provided in Section 994 leaves the court with greater discretion. ${ }^{87}$ According to Section 996(1) of the 2006 Companies Act, ${ }^{88}$ any form of remedy is feasible as long as the court deems it appropriate. This clause provides a wide range of remedies for minority shareholders oppressed by majority shareholders. Section 996(2) lists several possible unfair prejudice remedies. ${ }^{89}$ Among them, requiring the company or other members to purchase the shares of aggrieved shareholders plays the most critical role in protecting the rights and interests of minority shareholders. ${ }^{90}$ For public company, its shares are listed on the stock exchange, so that minority shareholders can sell their stocks at any time as the return of their investment. ${ }^{91}$ As a result, the risks of shareholders of public companies being oppressed by controlling shareholders are greatly decreased. In addition, at this time, the stock exchange market not only be regarded as an exit scheme for shareholders, but also provides a fair value evaluation mechanism. ${ }^{92}$ However, for minority shareholders of private companies, especially quasi-partnership companies, there is no public market for shareholders, and selling stocks is subject to many restrictions. At the same time, the dividends received by the minority shareholders of the private company is largely determined by the actual controller of the company. Therefore, the share purchase order is the most commonly used remedy, ${ }^{93}$ it provides the most direct compensation for minority shareholders oppressed by the controlling shareholders. ${ }^{94}$ Especially for closed companies and companies with a partnership nature, unnecessary trouble can be avoided by ordering other shareholders or companies to purchase shares of aggrieved members. ${ }^{95}$

The buy-out order is also one of the most acceptable unfair prejudice remedies by the petitioner and the court in practice. ${ }^{96}$ When the interests of the members of a company are unfairly infringed upon, the foundation of mutual trust and understanding among shareholders is destroyed. For minority shareholders, the best solution is to sell the shares and exit the company. ${ }^{97}$ Purchasing the shares of the aggrieved shareholders by the members who conducted the unfair prejudice or by the company, on the one hand, could make the non-controlling shareholders no longer trapped in the internal contradictions of the company and get the due return; on the other hand, it can also make the company focus on its own business activities. For example, in Bilkus $v$ King, King and Bilkus reached an oral agreement as to the future

${ }^{84}$ Gross v Rackind, [2005] 1 W.L.R. 3505

${ }^{85} \mathrm{Ibid}$.

${ }^{86}$ Companies Act 2006, section 996

${ }^{87}$ Companies Act 2006, section 994

${ }^{88}$ Companies Act 2006, section 994, 996

${ }^{89}$ Companies Act 2006, section 996(2)

${ }^{90}$ Sarah Worthington and L. S. Sealy, Sealy and Worthington's Text, Cases and Materials in Company Law (11th edn, Oxford University Press 2016) 747

${ }^{91}$ Sarah Worthington and L. S. Sealy, Sealy and Worthington's Text, Cases and Materials in Company Law (11th edn, Oxford University Press 2016) 741

${ }^{92}$ M Rishi Kumar Dugar, 'Minority Shareholders Buying Out Majority Shareholders - An Analysis' (2010) 22 Natl L Sch India Rev 105

${ }^{93}$ Derek French, Stephen W Mayson and Christopher Ryan, Mayson, French \& Ryan On Company Law (2017-2018 edn, Oxford University Press 2017) 586

${ }^{94}$ M Rishi Kumar Dugar, 'Minority Shareholders Buying Out Majority Shareholders - An Analysis' (2010) 22 Natl L Sch India Rev 105

${ }^{95}$ Arthur R Pinto, 'Protection of Close Corporation Minority Shareholders in the United States' (2014) 62 Am J Comp L Supp 361

${ }^{96}$ Sarah Worthington and L. S. Sealy, Sealy and Worthington's Text, Cases and Materials in Company Law (11th edn, Oxford University Press 2016) 725

${ }^{97}$ M Rishi Kumar Dugar, 'Minority Shareholders Buying Out Majority Shareholders - An Analysis' (2010) 22 Natl L Sch India Rev 105 
ownership and control of the company prior to the incorporation. ${ }^{98}$ In August 2000, King excluded Bilkus from further participation in the management of the Company. ${ }^{99} \mathrm{He}$ subsequently also declined to issue to Bilkus a one-half shareholding in the equity of the Company. On January 30, 2002 Bilkus presented an unfair prejudice petition. ${ }^{100}$ The relief sought was that King be ordered to sell to Bilkus the share registered in his name. ${ }^{101}$ The court held that seeking an order for the purchase of his shares is the most appropriate way for a petitioner to a fair result. ${ }^{102}$

The purpose of this remedy is to enable separation between the members who have difficulty continuing cooperation. In Grace v Biagioli, the court noted that under the unfairly prejudice provisions, the discretion of the court as to remedy was not limited to merely reversing or putting right the immediate conduct that had justified the making of the order. ${ }^{103}$ The most appropriate order to deal with internal disputes in small private companies would normally be a share purchase order. In most cases of proven fault, anything less than a clean break was unlikely to satisfy the objectives of the court's power to intervene. Having made the finding of unfair prejudice, the court should then have considered the position more comprehensively and should have concluded that a buy-out order was the sure and fair way of dealing with the situation that had occurred. ${ }^{104}$

Therefore, on the one hand, compared with the just and equitable winding up, the unfair prejudice mechanism could avoid the company being sentenced to death through appropriate relief measures. On the other hand, compared with the derivative action, the remedy of unfair prejudice is more extensive and diversified, among which the share purchase order plays the significant role.

\title{
3.3. The Balance Between Corporate Autonomy and Judicial Intervention
}

The relief order issued by the court in accordance with the Section 996 of the Companies Act 2006 would actually cause interference in company affairs, ${ }^{105}$ and inevitably pose a threat to the autonomy of the company. ${ }^{106}$ Moreover, such intervention is generally specific, which contradicts the position that the court does not interfere in the internal affairs of the company. However, the purpose of the unfair prejudice provisions is to put right improper decision-making and misconduct within the company through judicial intervention. ${ }^{107}$ This reflects the balance between autonomy of the company and interference of the court, and can provide effective protection to the minority shareholders who have been infringed by controlling shareholders.

Neither the company's articles of association nor shareholders' agreements can fully stipulate the rights and obligations of every member and director of the company. As a result, the company's articles of association often fail to effectively prevent the shareholder oppression within the company. In fact, agreements between shareholders are often informal, especially in quasi-partnership companies. Therefore, the protection of minority shareholders requires external interference and control, and the unfair prejudice provisions just reflects this consideration. On the one hand, aggrieved shareholders could sue the actual controller of the company for unfair prejudice conducts according to the Companies Act $2006,{ }^{108}$ and there is no exception to exclude the application of this provision through entering into an agreement. On the other hand, the review of the court is not only limited to the company's articles of association and written agreements, but also tends to take into account the legitimate expectations of minority shareholders based on the trust and understanding among members of the company. ${ }^{109}$ In addition, although Section 996 of the Companies Act lists different types of remedies, ${ }^{110}$ the most commonly used by the court is the buy-out order, since it does not directly interfere with the internal affairs of the company. ${ }^{111}$ Usually the courts reluctant to do more than provide the petitioner an opportunity

\author{
${ }^{98}$ Bilkus v King, [2003] EWHC 2516 (Ch) \\ 99 Ibid. \\ 100 Ibid. \\ 101 Ibid. \\ 102 Ibid. \\ 103 Ibid. \\ ${ }^{104}$ Sarah Worthington and L. S. Sealy, Sealy and Worthington's Text, Cases and Materials in Company Law (11th edn, \\ Oxford University Press 2016) 717 \\ 105 Companies Act 2006, section 996 \\ 106 Zhong Xing Tan, 'Unfair Prejudice from beyond, beyond Unfair Prejudice: Amplifying Minority Protection in \\ Corporate Group Structures' (2014) 14 J Corp L Stud 367 \\ ${ }^{107}$ Robert Goddard, 'Excessive Remuneration and the Unfair Prejudice Remedy ' (2009) 13 Edinburgh L Rev 517 \\ ${ }^{108}$ Companies Act 2006, section 994 \\ ${ }^{109}$ Sarah Worthington and L. S. Sealy, Sealy and Worthington's Text, Cases and Materials in Company Law (11th edn, \\ Oxford University Press 2016) 732 \\ ${ }^{110}$ Companies Act 2006, section 996 \\ ${ }^{111}$ Sarah Worthington and L. S. Sealy, Sealy and Worthington's Text, Cases and Materials in Company Law (11th edn,
}


to exit from the company and get the return of investment through a buy-out order, which also reflects the balance between corporate autonomy and judicial intervention.

\section{WEAKNESS OF UNFAIR PREJUDICE}

\subsection{Time-Consuming and Costly Process}

Although the relatively vague concept of unfair damage is beneficial to protect the interests of minority shareholders to some extent, it would also lead to certain disadvantages. According to Companies Act $2006,{ }^{112}$ courts were capable of interpreting the provisions gradually as they felt would be fair. In addition, when the affairs of the company are being or have been conducted in a manner that is unfairly prejudicial to the interests of members, the aggrieved shareholders could make an application to the court according to the section $994 .{ }^{113}$ While expanding the scope of application of the unfair prejudice mechanism, it also increased the burden on the court. Moreover, due to the protection of the legitimate expectations of minority shareholders, the objects reviewed by the court include but are not limited to the company's articles of association. This not only increases the time spent in the hearing, but also the cost of the petitioner. ${ }^{114}$ Take Elgindata Ltd as an example, the 43-day hearing cost 320,000 pounds, and the value of the stock fell from about 40,000 pounds to 24,600 pounds. ${ }^{115}$ In Macro (Ipswich) Ltd, the hearing occupied 25 days and ranged over 40 years of the history of the company. ${ }^{116}$

\subsection{Potential Damage to the Company}

In the case of unfair prejudice, the court not only needs to determine whether the conducts are unfair prejudicial to the interests of members, but also needs to consider the specific circumstances and requirements of both parties when issuing a relief order. The long-term hearing may affect the normal operation of the company, and indirectly lead to potential damage to the company and the other shareholders. ${ }^{117}$ On one hand, hearing will distract the company from its operations, which would affect the profits and the stock prices. On the other hand, it will erode the reputation of the company, which may even lead to the bankruptcy.

\subsection{The Negative Impact of the Court's Discretion}

The statutory unfair prejudice provisions conferred on the court a wide discretion to do what was fair and equitable. However, such discretion without clear limits is dangerous. The court's abuse of discretion may excessively interfere with the internal affairs of company, which may have a detrimental impact on the normal operation of the company. ${ }^{118}$ In addition, this discretion of the court may be abused by minority shareholders and cause excessive protection. The company is the carrier of the common interests of all shareholders, and the interests of the company and minority shareholders may be reversed in some cases. In order to balance the interests between non-controlling shareholders and controlling shareholders, the court must to apply the discretion reasonably and comprehensively consider the circumstances of each specific case to find the most suitable and fair way.

\section{CONCLUSION}

The statutory unfair prejudice provisions under Companies Act 2006 empowers the minority shareholders to bring an action against the majority shareholders when their conduct has an effect that is unfairly prejudicial to the interests of the minority shareholders. The defining feature of the unfair prejudice under Section 994 is that it is completely vague, with the result that courts were capable of interpreting the provisions gradually as they felt would be fair. Compare with the alternative remedy to winding up in cases of oppression provided in Section 210(1) of the Companies Act 1948, ${ }^{119}$ the petitioner seeking unfair prejudice remedies does not need to provide any evidence to prove the subjective intention of

Oxford University Press 2016) 725

${ }^{112}$ Companies Act 2006

${ }^{113}$ Derek French, Stephen W Mayson and Christopher Ryan, Mayson, French \& Ryan On Company Law (2017-2018 edn, Oxford University Press 2017) 574

114 Ibid.

${ }^{115}$ Re Elgindata (No.1), [1991] B.C.L.C. 959

116 Re Macro (Ipswich) Ltd, [1994] 2 B.C.L.C. 354

117 Sarah Worthington and L. S. Sealy, Sealy and Worthington's Text, Cases and Materials in Company Law (11th edn, Oxford University Press 2016) 723

${ }^{118}$ Arthur R Pinto, 'Protection of Close Corporation Minority Shareholders in the United States' (2014) 62 Am J Comp L Supp 361

${ }^{119}$ Companies Act 1948, section 210(1) 
the majority shareholders. With the development of common law, it should be noted that the unfair prejudice action does protect the legitimate expectations of shareholders. In practice, it most commonly occurs in private companies, because the lack of a public market for shares leaves minority shareholders particularly vulnerable. Consequently, in private companies, the minority shareholders cannot escape unfair prejudice conduct by selling their stock and exiting the corporation. In addition, this mechanism for minority protection emphasizes the judicial intervention with extensive and diversified remedies.

Although the Section 994 of Companies Act 2006 provided a successful mechanism for minority protection, it is not without any shortcomings. Courts often have to conduct complex reviews to find out what is really going on in an unfair prejudice case, leading to a lengthy and costly process. This would not only have a negative impact on the interests of the aggrieved shareholders, but also cause the distractions of the company in commercial operations. At the same time, the company would suffer a blow to its reputation, and may eventually result in a complete deadlock.

\section{Cases}

\section{BIBLIOGRAPHY}

Foss v Harbottle, [1843] 3 WLUK 93

Meyer v Scottish Cooperative Wholesale Society Ltd, [1959] AC 324

Ebrahimi v Westbourne Galleries Ltd, [1972] 2 W.L.R. 1289

Re Bird Precision Bellows Ltd, [1986] 2 W.L.R. 158

Re Kenyon Swansea Ltd, [1987] B.C.L.C. 514

Re Elgindata (No.1), [1991] B.C.L.C. 959

Re Macro (Ipswich) Ltd, [1994] 2 B.C.L.C. 354

Re Saul D Harrison \& Sons Plc, [1995] 1 B.C.L.C. 14

O'Neill v Phillips, [1999] 1 W.L.R. 1092

Bilkus v King, [2003] EWHC 2516 (Ch)

Gross v Rackind, [2005] 1 W.L.R. 3505

Grace v Biagioli, [2006] 2 B.C.L.C. 70

\section{Statutes}

Companies Act 1948

Companies Act 1980

Companies Act 1985

Companies Act 2006

\section{Books}

Davies P L and Worthington S, Gower's Principles of Modern Company Law (10th edn, Sweet \& Maxwell 2016)

French D, Mayson S W and Ryan C, Mayson, French \& Ryan On Company Law (2017-2018 edn, Oxford University Press 2017)

Worthington S and Sealy L S, Sealy and Worthington's Text, Cases and Materials in Company Law (11th edn, Oxford University Press 2016)

\section{Journal Articles}

Atwal H, 'Self-Interest, Justice and Reciprocity in Unfair Prejudice' (2004) 2004 UCL Jurisprudence Rev 270

Dugar M R K, 'Minority Shareholders Buying Out Majority Shareholders - An Analysis' (2010) 22 Natl L Sch India Rev 105

Furey N, 'The Statutory Protection of Minority Shareholders in the United Kingdom' (1987) 22 Wake Forest L Rev 81

Goddard R, 'Excessive Remuneration and the Unfair Prejudice Remedy ' (2009) 13 Edinburgh L Rev 517

Goo S H and Weber R H, 'The Expropriation Game: Minority Shareholders' Protection' (2003) 33 Hong Kong LJ 71

Gross N B, 'Figaro, Ferrari and Unfair Prejudice - Can Creditors Actually Use the Oppression Remedy: Canadian Opera Company v. Euro-American Motor Cars' (1991) 13 Advoc Q 115

Ming W W C, 'A Note on Unfair Prejudice - Section 75 of the U.K. Companies Act 1980' (1983) 25 Malaya L Rev 396 Nwafor A O, 'The Unfair Prejudice Remedy - A Relief for the Minority Shareholders' (2011) 13 U Botswana LJ 37

Payne J, 'Shareholders' Remedies Reassessed' (2004) 67 Mod L Rev 500

Pinto A R, 'Protection of Close Corporation Minority Shareholders in the United States' (2014) 62 Am J Comp L Supp 361

Stapledon G P, 'Negligence as Unfair Prejudice' (1992) 4 Corp Bus LJ 77

Tan Z X, 'Unfair Prejudice from beyond, beyond Unfair Prejudice: Amplifying Minority Protection in Corporate Group Structures' (2014) 14 J Corp L Stud 367 